\title{
A NEW REGULATION FOR SUPPORTING A CIRCULAR ECONOMY IN THE PLASTIC INDUSTRY: THE CASE OF PERU (SHORT COMMUNICATION)
}

\author{
ALDO AlvarEZ-RISCO ${ }^{1 *}$, MARC A. ROSEN ${ }^{2}$ \\ AND SHYLA DEL-AGUILA-ARCENTALES ${ }^{3,4}$ \\ ${ }^{1}$ Universidad de San Martin de Porres, Lima, Peru \\ ${ }^{2}$ University of Ontario Institute of Technology, Oshawa, Ontario, Canada \\ ${ }^{3}$ Universidad de la Amazonia Peruana, Iquitos, Peru \\ ${ }^{4}$ Escuela Nacional de Marina Mercante “Almirante Miguel Grau”, Callao, Peru \\ *Corresponding authore-mail: aalvarezr@usmp.pe
}

Received: $7^{\text {th }}$ December 2019, Accepted: $21^{\text {th }}$ December 2019

\begin{abstract}
The present study shows the regulatory proposal related to plastic by the Peruvian government and also, the previous initiatives are described so that it can be taken as a reference for the successful implementation in other countries, taking into account the regulatory and business aspects at the same time.
\end{abstract}

Keywords: plastic, circular economy, Peru, sustainability

Some global initiatives linked to sustainable development and management need national efforts. These in turn often require national targets or goals. A noteworthy example is the Aichi Biodiversity Targets (CBD, 2015), specifically Target 4 (by 2020, at the latest, governments, business and stakeholders at all levels have taken steps to achieve or have implemented plans for sustainable production and consumption...), Target 11 (by 2020, at least $17 \%$ of terrestrial and inland water, and $10 \%$ of coastal and marine areas, especially areas of particular importance for biodiversity and ecosystem services, are conserved ...) and Target 17 (by 2020 each party has developed, adopted as a policy instrument, and has commenced implementing an effective, participatory and updated national biodiversity strategy and action plan). Likewise, the United Nations Sustainable Development Goals (SDGs) and The Paris Agreement (UNFCC, 2018) are focused on sustainability and the protection of our environment.

The protection and conservation of the environment is one of the most important issues on the global agenda. Governments, multinational companies as well as the public and private organizations sometimes carry out actions to achieve sustainable development objectives in the short to medium term. Efforts in the areas of business practices, individual and organizational behavior and consumption patterns have become relevant for the achievement of an increasingly sustainable world. In line with this objective, a circular economy (CE) is often a cornerstone for new models of process of products. The optimal management of 
Alvarez-Risco A., Rosen M.A., Del-Aguila-Arcentales S.: A new regulation for supporting a circular economy in the plastic industry: The case of Peru

plastic waste, a significant issue in the implementation of a $\mathrm{CE}$, is in need of urgent attention if it is to fulfill current international norms and agreements. Peru, since it was the organizer of COP 20, began to develop initiatives based on the commitments made to contribute to sustainable development.

Successful implementation of a CE in the value-chain of plastics requires more and better communication between relevant stakeholders (Simon, 2019). In line with this requirement, the Ministry of the Environment of Peru recently developed and approved the Law $\mathrm{N}^{\circ} 3084$, entitled "Law that regulates single-use plastics and disposable containers" [Ley que regula el plástico de un solo uso y los recipientes o envases descartables] (Gobierno del Perú, 2018). This law aims to contribute to the realization of the right of every person to enjoy a balanced and appropriate environment for the development of their lives, and to reducing the adverse impact of single-use plastics, including plastic marine garbage and fluvial and lacustrine and other similar pollutants, on human health and the environment. The law establishes a progressive reduction of the use of polymer-based bags, which must be replaced progressively within a period that expires in December 2021. Non-reusable polymeric based bags must be progressively replaced with reusable bags or other products whose degradation does not generate contamination in the form of microplastics or dangerous substances, and for which recovery is ensured. As of April 2019, Peru will have prohibited the acquisition, use or commercialization of polymer-based bags, as well as polymer-based sorbets such as straws and containers or containers of expanded polystyrene for beverages and food for human consumption, in natural protected areas, areas declared cultural heritage or natural heritage of humanity sites, museums, beaches on the coast and shores of the Peruvian Amazon. Also, it will not be allowed to utilize polymer-based bags or wrappings for printed advertising; for newspapers, magazines and other written press materials; for receipts for collection of services, whether public or private; and for all information addressed to consumers, users or citizens in general. As of January 2020, the manufacturing for domestic consumption, import, distribution, delivery, marketing and consumption will be prohibited of polymer-based bags whose size has an area of less than nine hundred square centimeters $\left(900 \mathrm{~cm}^{2}\right)$ and whose thickness is less than fifty microns $(50 \mu \mathrm{m})$. Another prohibition that also is approved for January 2021 is the manufacture for domestic consumption, import, distribution, delivery and consumption, under any modality, of polymeric plastic bags, which are not reusable and whose degradation generates contamination by microplastics or dangerous substances and do not ensure their recovery.

Also, registration is required of manufacturers, importers and distributors of goods regulated under this law as is the generation of relevant statistical information. It was also suggested that the Ministry of the Environment, the Ministry of Education, the Ministry of Production and decentralized governments in Peru develop actions or activities to promote education, training and awareness. The disruptive aspects of the law are threefold:

a. An obligation to use recycled materials in bottles of polyethylene terephthalate (PET). This indicates, for example, that manufacturers of polyethylene terephthalate (PET) bottles for beverages for human consumption, personal hygiene and similar uses, must be included in the productive chain post-consumer recycled PET material (PET-PCR) with at least fifteen percent $(15 \%)$ of its composition, complying with food safety standards.

b. The existence of a certificate of biodegradability of plastic products.

c. A consumption tax on plastic bags, introduced and applied gradually. The tax is based on the acquisition of plastic bags, according to the following schedule: 0.03 USD/bag in 2019, 
0.06 USD/bag in 2020, 0.09 USD/bag in 2021, 0.12 USD/bag in 2022 and subsequent years. This tax becomes effective on August 1 of the year 2019.

According to Xanthos \& Walker (2017), the first plastic bag policy interventions occurred in Germany in 1971, followed by Denmark (1998), Bangladesh, Ireland, South Africa and India (2002), Taiwan (2003), Rwanda (2004), Eritrea (2005), Tanzania (2006), Botwana, Canada, Kenya and the USA (2007), China (2008) and other countries in more recent years. One question that arises is whether the implementation of these prohibitions and taxes will actually achieve the positive changes that the authorities expect, since Xanthos \& Walker (2017) report is that some countries have put little effort into the tax despite its approval. This is the case for Bangladesh, while for South Africa the level of consumption remains high. The outcomes in Taiwan and Hong Kong are interesting since the tax was overturned in the food services sector due to hygiene concerns. Note that in Toronto and Italy this tax has not been implemented due to its rejection by the Toronto authorities and disputes regarding EU trade laws, respectively.

What determines the success of a ban and the tax on the use of single-use plastic bags? The commitment of the authorities to support efforts and, at same time, aggressive education to the population appear to be essential. However, some factors, often unforeseen, such as hygienic measures can generate exceptions.

This leadership of Peru for the sustainable management of the use of plastic bags will likely have an impact in the short term on other countries of Latin America, and may cause more countries to join these measures as well as others to protect local and global water resources.

\section{Disclosure of interest}

The authors declare that they have no competing interest

\section{REFERENCES}

CBD, (2015). Aichi Biodiversity Targets. Retrieved on 13 January 2019 from https://www.cbd.int/sp/targets/.

Gobierno del Perú, (2018). Law that regulates the plastic of a single use and the disposable containers. Retrieved on 13 January 2019 from https://busquedas.elperuano.pe/ normaslegales/ley-que-regula-el-plastico-de-un-solo-uso-y-los-recipientes-ley-n-30884-172 4734-1/

Simon, B., (2019). Circular economy-from review of theories and practices to development of implementation tools. Resour. Conserv. Recycl. Sustain. Resour. Manage. Circ. Econ. 135, 190-201. https://doi.org/10.1016/j.resconrec.2018.10.044

UNFCC, (2018). The Paris Agreement. Retrieved on 13 January 2019 from https://unfccc.int/process-and-meetings/ the-paris-agreement/the-paris-agreement.

Xanthos, D., \& Walker, T. R., (2017). International policies to reduce plastic marine pollution from single-use plastics (plastic bags and microbeads): a review. Marine pollution bulletin, 118(1-2), 17-26. https://doi.org/10.1016/j.marpolbul.2017.02.048. 